\title{
Zoonotic Potential of Escherichia Coli in Poultry Intestinal Contents in Ismailia City, Egypt with Special Reference to Shiga Toxin-Producing (STEC) Strains
}

\author{
Al-Qabili M. The yazan', Aboue is ha M. Abdelkarim², Hanaa M. \\ Fade $^{2}$ and Youssef I. Ahmed ${ }^{2 *}$ \\ ${ }^{1}$ Agriculture and Veterinary Medicine College, Thamar University, \\ Yemen. \\ ${ }^{2}$ Department of Zoonoses, Faculty of Veterinary Medicine, Suez \\ Canal University, Ismailia, Egypt.
}

* Corresponding author: Ahmed I. Youssef, PhD

Tel / Fax: +2-0643207052 E-Mail: ahmed_ibrahim@vet.suez.edu.edu

\begin{abstract}
Avian colibacillosis can affect birds of all ages. It is now one of the major causes of economic losses in the poultry industry, as well as a public health risk all over the world. This study aimed to determine the occurrence of E. coli in market-age poultry and the risk of its zoonotic infections in Ismailia city, Egypt. A total of 350 samples were collected from the intestinal contents of the slaughtered poultry (100 farm chickens, 100 backyard chickens, 50 ducks, 50 geese, and 50 turkeys) in Ismailia City. On the other hand, a total of 200 samples were collected from humans at outpatient clinics (100 stool samples and 100 urine samples) from the same investigated area. Samples were examined using bacteriological and molecular examination for genus-specific and virulence gene detection. Results revealed that the isolation rates of $E$. coli were $70 \%$ in farm chickens and turkeys, $88 \%$ in backyard chickens, $86 \%$ in domestic ducks, $72 \%$ in geese. Of avian E. coli isolates, the rates of Shiga toxin-producing E. coli (STEC) strains were 91.4\%, 96.6\%, $90.9 \%, 41.7 \%$, and $51.4 \% \%$ in farm chickens, backyard chickens, ducks, geese, and turkey respectively. In humans, the isolation rate of $E$. coli was $42 \%$ in urine samples and $66 \%$ in stool samples. The human STEC isolates were higher in stool samples (26\%) than in urine samples $(6 \%)$. The isolation rates of $E$. coli were significantly higher in persons who were in contact with poultry than in persons who were not in contact with poultry $(\mathrm{p} \leq 0.01)$. In conclusion, the high
\end{abstract}


isolation rates of STEC and detection with similarities of some E. coli virulence genes (It, St, eaeA, Stx1, and Stx2 genes) from poultry intestinal contents and human samples indicated a significant risk of zoonotic transmission of E. coli via food chain in the investigated area.

Keywords: Escherichia coli, poultry, STEC, zoonotic, Ismailia.

\section{Introduction}

Escherichia coli $(E$. coli) is a type of microbial flora commonly found in the gastrointestinal tracts of chickens, humans, and other animals. Although E. coli is part of the normal microbiota of the poultry gut, certain strains, such as avian pathogenic E. coli (APEC), can spread to numerous internal organs, causing colibacillosis, which is accompanied by systemic infections and mortalities ( $\boldsymbol{L a}$ Ragione and Woodward, 2002, Kathayat et al., 2021). avian colibacillosis is one of the most common endemic diseases affecting the poultry industry globally, resulting in significant economic losses. It has been estimated that $10-15 \%$ of the $E$. coli strains commonly found in the chicken intestine are potentially pathogenic (Dziva and Stevens, 2008).

E. coli is the most common foodborne pathogen of public health concern found in poultry flesh around the world. The most common way pathogenic E. coli bacteria are one of the most frequent foodborne infections, affecting millions of people each year, with severe and fatal consequences in some cases $E$. coli enters the human food chain is by faeces or intestinal contents after slaughter, and inter-human transmission can occur via the faecal-oral pathway (Yang et al., 2017). Human strains of the extraintestinal pathogen $E$. coli (ExPEC) caused urinary tract infections (UTIs), meningitis in newborns, or blood poisoning (Mora et al., 2009).

Enterotoxigenic E. coli (ETEC), enteroinvasive $E$. coli (EIEC), enteroaggregative $E$. coli (EAEC), enterohemorrhagic (EHEC)/Shiga toxin-producing E. coli (STEC), enteropathogenic $E$. coli (EPEC), and diffusely adherent E. coli (DEC) are the six pathotypes of diarrheagenic Escherichia coli (DEC) (Nataro and Kaper, 1998).

STEC, also known as verotoxin $E$. coli, is a zoonotic pathogen of public health concern whose sources and transmission routes are difficult to trace (MughiniGras et al., 2018). The STEC is a set of foodborne pathogenic 
bacteria that have been related to a variety of human illnesses, including diarrhea, hemorrhagic colitis (HC), thrombocytopenia, and hemolytic uremic syndrome (HUS), as well as human death. Shiga toxins (Stx) are the main virulence factors that contribute to the organism's pathogenicity. There are two types of toxins: stx1 and stx2 (Karch et al., 2005). Consumption of minced meat, raw/undercooked meat, or cured meat/cold cuts was linked to human STEC infections (Mughini-Gras et al., 2018 and Tanabe et al., 2019). In general, STEC infection is spread via eating or handling contaminated food, as well as contact with infected animals or birds. Close contact, such as within families, at schools, and in long-term care facilities, allows for further person-to-person transmission (Busani et al. 2006).

Enterotoxigenic E. coli strains cause diarrhea mostly in children, especially in areas where cleanliness and hygiene are inadequate (Kaper et al., 2004). Enterotoxigenic E. coli is most usually associated with traveler's diarrhea, but it is also a significant diarrheal pathogen in babies (Ogata et al., 2002). The plasmid-encoded, heatlabile (LT), and heat-stable (ST) enterotoxins are two main virulence factors in the (ETEC) (Feng and Reddy, 2013). Enterotoxigenic $E$. coli is a typically food-borne pathogen causing HC or HUS. Typical EHEC strains produce Shigalike toxins which are characterized by the STEC strains to be the most virulent diarrhoeagenic E. coli (Kaper et al., 2004).

In view of the lack of information on the health and risk of poultry intestinal content E. coli, the present study was undertaken to determine the occurrence of E. coli spp. in poultry intestinal contents and some virulence genes of $E$. coli isolates with identifying their zoonotic potential in Ismailia City, Egypt.

\section{Mate rials and methods Sampling:}

A total of 350 poultry intestinal content samples $(100$ farm chickens, 100 backyard chickens, 50 ducks, 50 geese, and 50 turkeys) were collected from live poultry retail shops in Ismailia city, Egypt. The live bird shops were selling live birds and offering on-site slaughtering and de-feathering and evisceration. The samples were collected soon after the evisceration of the selected poultry on the day of collection by taking the whole intestines of the slaughtered domestic poultry in sterile plastic bags. On the other hand, a total of 200 human samples (100 stool samples and 100 urine samples) were 
collected from out- and in-clinic patients of Ismailia university hospital and Ismailia General Hospital after signed on informed consent for each case. The stool samples were collected from symptomatic patients with diarrhea and the urine samples were collected from patients who had symptoms of UTI (dysuria). Specimen of urine generally collected from midstream urine in sterile plate universal containers with high precautions of contamination.

Questionnaires were directed to all patients who were participated in this study and included the name, sex, age, date of sample collection, address, and occupations, contact with poultry, feeding habits, and health status.

All the samples were transported immediately after collection in ice box under complete aseptic conditions to Zoonoses Laboratory, Department of Hygiene, Zoonoses and Animal Ethology, Faculty of Veterinary Medicine, Suez Canal University for processing, isolation, and identification of $E$. coli species.

Bacteriological isolation and identification of $E$. coli species In poultry samples, swabs were taken by sterile cotton swabs from the intestinal contents of the lower parts of the poultry intestinal tract under complete aseptic conditions. In human urine samples, one $\mathrm{ml}$ of urine was taken by sterile pipette from each human urine sample. The swabs and urine samples were inoculated primarily in tubes, each of them containing $9 \mathrm{ml}$ of E. coli broth (OXOID, UK), followed by incubation at $37{ }^{\circ} \mathrm{C}$ for 18-24 hours. A loopful from each incubated broth culture was cultured by streaking onto Eosin methylene blue (EMB) agar (OXOID, UK) and incubated at $37{ }^{\circ} \mathrm{C}$ for $24 \mathrm{~h}$. Colony morphologically resembling E. coli (metallic green sheen) was carefully picked and repeatedly subcultured onto EMB agar until the pure culture with homogenous colonies was obtained. A single colony from each pure culture was then subcultured onto nutrient agar to check for purity and identification confirmed by microscopic examination and biochemical tests. Fixed films of suspected colonies were stained with Gram's stain then examined under an oil immersion lens. All the isolates were identified to $E$. coli spp. biochemically as described by

MacFaddin (2000)

Isolation of STEC strains by culturing on CHROMagar STEC medium

All the confirmed E. coli isolates were submitted for 
further examination by subculturing on CHROM agar STEC for detection of STEC as described by Hirvonen et al., (2012). A loopful from each broth culture positive for $E$. coli was sub-cultured by streaking onto CHROMagar STEC (Chromogenic Media Pioneer) and then incubated at $37{ }^{\circ} \mathrm{C}$ for $24 \mathrm{~h}$.

DNA Extraction and PCR amplifications:

A total of 210 positive E. coli broth cultures (150 of poultry and 60 of humans), which were confirmed by subculturing on EMB agar and then by microscopic examination and biochemical tests, submitted for further examination by PCR for the detection of genus-specific GAD ( $\operatorname{gadA} / B$ genes) and the virulence genes of $E$. coli isolate. The primers were ordered from Biobasic, Canada as nucleotide sequences. All primers were diluted according to the company instructions using sterile MilliQ water (Table, 1).

Total DNA was extracted from the E. coli by using QIAamp
DNA Stool Mini Kit, as per manufacturer instructions. The PCR reaction mix consisted of a total reaction volume of $25 \mu \mathrm{l}$ containing $12.5 \mu \mathrm{l}$ of $2 \mathrm{X}$ PCR master mix (Gendirx), $0.2 \mu \mathrm{l}$ of each primer (Forward \& reverse) (Concentration 10 pmol), $3 \mu \mathrm{l}$ of the extracted DNA from E. coli isolates, and sterile distilled water up to $25 \mu$. The thermal profile of the PCR amplification was used as per the initial authors. The PCR products $(10 \mu l)$ were separated by electrophoresis in $1.2 \%$ (wt/vol), agarose in $1 \mathrm{X}$ TBE containing $0.2 \mu \mathrm{g} / \mathrm{ml}$ ethidium bromides. Images were recorded with a gel documentation system.

\section{Statistical Analys is}

All the present data were analyzed statistically using the Chi-square test for association and relationship between categorical variables. Results were considered significant at $(P \leq 0.05)$ use Statistical Package for the Social Sciences (SPSS) software version 24. 
Table 1. Targeted genes and primer sequences used in PCR assays

\begin{tabular}{|c|c|c|c|c|}
\hline $\begin{array}{l}\text { Target } \\
\text { Gene }\end{array}$ & $\begin{array}{l}\text { Primer } \\
\text { Name }\end{array}$ & Primer sequence (5 -3) & $\begin{array}{c}\text { PCR } \\
\text { product } \\
\text { size (bp) }\end{array}$ & References \\
\hline \multirow{2}{*}{ E. coli Spp. } & \multirow{2}{*}{$\operatorname{gad} A / B$} & ACCTGCGTTGCGTAAATA & \multirow{2}{*}{670} & \multirow{2}{*}{$\begin{array}{c}\text { (McDaniel et al., } \\
\text { 1996) }\end{array}$} \\
\hline & & GGGCGGGAGAAGTTGATG & & \\
\hline \multirow{4}{*}{ ETEC } & \multirow{2}{*}{ It } & GGCGACAGATT AT ACCGT GC & \multirow{2}{*}{450} & \multirow{6}{*}{ (Lee et al., 2009) } \\
\hline & & CGGTCTCTATATTCCCTGTT & & \\
\hline & \multirow{2}{*}{ St } & ATTTTTCTTTCTGTATTGTCTT & \multirow{2}{*}{190} & \\
\hline & & CACCCGGT ACAAGCAGGATT & & \\
\hline \multirow{4}{*}{ EPEC } & \multirow{2}{*}{ bfpA } & AATGGTGCTTGCGCTTGCTGC & \multirow{2}{*}{324} & \\
\hline & & GCCGCTTTATCCAACCTGGT A & & \\
\hline & \multirow{2}{*}{ eaeA } & GACCCGGCACAAGCAT AAGC & \multirow{2}{*}{384} & \multirow{2}{*}{$\begin{array}{l}\text { (Lopez-Saucedo } \\
\text { et al., 2003) }\end{array}$} \\
\hline & & CCACCTGCAGCAACAAGAGG & & \\
\hline \multirow{4}{*}{ EHEC } & \multirow{2}{*}{ Stx 1} & CTGGATTTAATGTCGCATAGTG & \multirow{2}{*}{150} & \multirow{6}{*}{ (Lee et al., 2009) } \\
\hline & & AGAACGCCCACTGAGATCATC & & \\
\hline & \multirow{2}{*}{ Stx 2} & GGCACTGTCTGAAACTGCTCC & \multirow{2}{*}{255} & \\
\hline & & TCGCCAGTT ATCTGACATTCTG & & \\
\hline \multirow{2}{*}{ EIEC } & \multirow{2}{*}{ Ial } & GGT ATGATGATGATGAGTCCA & \multirow{2}{*}{650} & \\
\hline & & GGAGGCCAACAATTATTTCC & & \\
\hline \multirow{2}{*}{ EAEC } & \multirow{2}{*}{ Aafll } & CACAGGCAACTGAAATAAGTCTGG & \multirow{2}{*}{378} & \multirow{2}{*}{$\begin{array}{l}\text { (Vidal et al., } \\
\text { 2005) }\end{array}$} \\
\hline & & ATTCCCATGATGTCAAGCACTTC & & \\
\hline
\end{tabular}

\section{Results}

Prevalence of $E$. coli in poultry: As shown in table 2, the overall prevalence rate of $E$. coli in the examined poultry intestinal contents was $77.71 \%$ (272/350). The high prevalence rates of $E$. coli were in backyard chicken $(88 \%)$ and ducks $(86 \%)$ followed by geese $(72 \%)$, farm chickens (70\%), and turkeys $(70 \%)$. The difference between the prevalence rates of E. coli among the examined domestic poultry was significant $(P \leq$ $0.01)$. The positive samples for E. coli were further examined for STEC. The overall rate of STEC of positive $E$. coli isolates from samples from the intestinal contents of poultry was $81.62 \%$ (222/272), with high rates of STEC in the backyard chickens $(96.59 \%)$, ducks $(93.02 \%)$, and 
farm chicken (91.43\%) followed by turkeys (51.43) and geese $(41.67 \%)$. A high significant difference was found between the isolation rates of STEC among the examined domestic poultry $(P \leq 0.001)$.

Prevalence of $E$. coli in humans: As shown in table 3 , the overall prevalence rate of $E$. coli in the examined humans was $54 \%$ (108/200). The prevalence rate was significantly higher among stool samples $(66 \%)$ than urine samples $(42 \%)(P \leq 0.05)$. Among the positive E. coli isolates in the human specimen, the overall isolation rate of STEC was $29.63 \%$ (32/108). The occurrence of STEC isolates was significantly higher in the isolates from the stool specimens $(39.39 \%)$ than the isolates of urine specimens $(14.29 \%)(P \leq 0.01)$.

The occurrence rates of $E$. coli in human samples concerning their characteristic illustrated in table (4). The detection rates of E. coli and STEC in relation to age were higher in age groups $21-30$ years $(48.48 \%$ and $18.75 \%)$ and $31-40$ years (44\% and $18.18 \%$ ) followed by age groups $\leq 10$ years $(42.11 \%$ and $12.50 \%), 11-20$ years $(36.36 \%$ and $0.0 \%), \quad 41-50$ years $(28.57 \%$ and $0.0 \%)$ and $\geq 51$ years $(20 \%$ and $0.0 \%)$ in urine samples respectively. In stool samples, the rates of $E$. coli concerning age were higher in age groups $\leq 10$ years $(79.11 \%)$, $21-30$ years $(66.67 \%)$, and 3140 years $(60 \%)$ followed by age groups $11-20$ (54.16\%), 41-50 years $(50 \%)$ and $\geq 51$ years. While the detection rates of STEC were higher in age groups $\geq 51(100 \%)$ and $41-50$ years (50\%) followed by the other age groups which ranged from $33.33 \%$ to $42.86 \%$. The prevalence rates of E. coli and STEC in the human samples concerning gender were significantly higher in females $(49.15 \%$ and $17.24 \%)$ than males $(31.71 \%$ and $7.69 \%)$ in urine samples respectively $(\mathrm{P} \leq 0.01)$, while it was higher in males $(72.73 \%$ and $70.83 \%)$ than females $(62.69 \%$ and $37.50 \%)$ in stool samples, respectively ( $\mathrm{P}$ $\leq 0.01)$. Regarding the contact with poultry, the detection rates of $E$. coli in stool were higher in persons who were in contact with poultry $(48.43 \%$ and $84.48 \%$ ) than those not in contact with poultry $(30.55 \%$ and $40.47 \%$ ). While the rates of STEC isolates were higher in persons not in contact with poultry $(18.18 \%$ and $41.18 \%)$ than those who were in contact with poultry ( $12 \%$ and $38.78 \%)$. However, statistically, there were no significant differences $(\mathrm{p} \geq 0.05)$

The isolation rates of $E$. coli of human urine and stool samples, in relation to the season, were 
$28.57 \%$ and $53.84 \%$ in Summer, $50 \%$ and $61.9 \%$ in Autumn, $47.82 \%$ and $65.38 \%$ in Winter, and $42.1 \%$ and $72.5 \%$ in Spring, respectively. The difference between the isolation rates of $E$. coli in the different seasons of human urine and stool samples was significant $(\mathrm{p} \leq 0.05)$. However, there were no significant differences between the isolation rates of STEC in the different seasons of human urine and stool samples; $0.0 \%$ and $42.85 \%$ in Summer, $22.22 \%$ and $30.76 \%$ in Autumn, $9.09 \%$ and $35.29 \%$ in Winter, and $18.75 \%$ and $44.43 \%$ in Spring, respectively.

Occurrence of GAD and virulence genes in $E$. coli isolates of examined poultry illustrated in table (5). The overall detection rate of the $E$. coli GAD gene of the examined positive $E$. coli broth cultures of poultry intestinal contents was $90 \%(135 / 150)$. The rates of detection of E. coli GAD gene of positive $E$. coli broth cultures of the intestinal contents of farm chickens, backyard chickens, ducks, geese, and turkeys were $86.7 \%$, 93.3\% , 86.7\% , 93.3\% , and $90 \%$, respectively. The detected $E$. coli virulence genes were It, St, eaeA, Stx1, and Stx2, while Bfp, Ial, and Aafll genes were not detected in the examined positive E. coli broth cultures of the poultry intestinal contents. The detection rates of
It, St, eaeA, Stx1 and Stx2 genes respectively were $13.3 \%$, $16.7 \%, 16.7 \%, 3.3 \%$, and $23.3 \%$ in farm chickens, $13.3 \%, 23.3 \%$, $23.3 \%, 6.7 \%$ and $10 \%$ in backyard chickens, $6.7 \%, 20 \%$, $23.3 \%, 10 \%$ and $16.7 \%$ in ducks, $3.3 \%, 20 \%, 20 \%, 3.3 \%$ and $23.3 \%$ in geese and $16.7 \%$, $23.3 \%, 16.7 \%, 6.7 \%$ and $23.3 \%$ in turkeys. The rates of examined positive E. coli broth culture poultry samples have at least one $E$. coli virulence gene were $53.3 \%$ of farm chickens, $56.7 \%$ of backyard chickens, $60 \%$ of ducks, $53.3 \%$ of geese, and $70 \%$ of turkeys, while the rates of examined poultry samples have no virulence genes were $46.67 \%, 43.33 \%$, $40 \%, 46.67 \%$ and $30 \%$ of farm chickens, backyard chickens, ducks, geese, and turkeys, respectively.

On the other hand, as shown in table (6), the detection rates of GAD gene of $E$. coli of the examined positive E. coli broth cultures of human urine and stool samples were $80 \%$ (24/30) and $93.3 \%$ (28/30) respectively. E. coli virulence genes: It, St, eaeA, and Stx2 genes were detected in the examined positive $E$. coli broth cultures of human urine samples by rates of $20 \%, 20 \%, 26.7 \%$, and $23.3 \%$ respectively, while Bfp, Stx1, Ial, and Aafll genes were not detected. On the other hand, all tested virulence $E$. coli genes; It, 
St，Bfp，eaeA，Stx1，Stx2, Lal and Aafll were detected in human stool samples by rates of $20 \%, 23.3 \%, 3.3 \%, 10 \%, 3.3 \%$, $20 \%, \quad 13.3 \%$, and $10 \%$, respectively. The rates of examined positive E. coli broth cultures of human urine and stool samples have at least one E. coli virulence gene were $66.7 \%$ and $53.3 \%$ respectively, while the rates of examined human urine and stool samples have no virulence genes were $33.3 \%$ and $46.7 \%$, respectively.

Table 2. Prevalence of E. coli in the intestinal contents of domestic poultry

\begin{tabular}{|c|c|c|c|c|c|}
\hline \multirow[t]{2}{*}{ Source of samples } & \multirow{2}{*}{$\begin{array}{l}\text { TotalNo. } \\
\text { examined }\end{array}$} & \multicolumn{2}{|c|}{ Positive E.coli } & \multicolumn{2}{|c|}{$\begin{array}{l}\text { STEC / positive } E \text {. } \\
\text { coli samples }\end{array}$} \\
\hline & & No. & $(\%)$ & No & $\%$ \\
\hline Farm chick ens & 100 & 70 & 70 & 64 & 91.43 \\
\hline Backyard Chickens & 100 & 88 & 88 & 85 & 96.59 \\
\hline Ducks & 50 & 43 & 86 & 40 & 93.02 \\
\hline Geese & 50 & 36 & 72 & 15 & 41.67 \\
\hline Turkeys & 50 & 35 & 70 & 18 & 51.43 \\
\hline Total & 350 & 272 & 77.71 & 222 & 81.62 \\
\hline
\end{tabular}

E. coli $\left(\mathrm{X}^{2}=14.19, \mathrm{p} \leq 0.01\right)$

STEC $\left(X^{2}=\mathbf{8 0 . 9 2 8}, \mathbf{p} \leq \mathbf{0 . 0 1}\right)$

Table 3. Prevalence of E. coli among the human samples

\begin{tabular}{|l|c|c|c|c|c|}
\hline \multirow{2}{*}{ Source of samples } & \multirow{2}{*}{$\begin{array}{c}\text { TotalNo. } \\
\text { Examined }\end{array}$} & \multicolumn{2}{|c|}{ Positive E. coli } & \multicolumn{2}{|c|}{$\begin{array}{c}\text { TTC / positive } \boldsymbol{E} \text {. } \\
\text { coli samples }\end{array}$} \\
\cline { 3 - 6 } & & $\mathbf{N o .}$ & $\mathbf{\%}$ & No & $\mathbf{\%}$ \\
\hline Urine & 100 & 42 & 42 & 6 & 14.29 \\
\hline Stool & 100 & 66 & 66 & 26 & 39.39 \\
\hline Total & $\mathbf{2 0 0}$ & $\mathbf{1 0 8}$ & $\mathbf{5 4}$ & $\mathbf{3 2}$ & $\mathbf{2 9 . 6 3}$ \\
\hline
\end{tabular}

E. coli $\left(\mathrm{X}^{2}=11.594, \mathrm{p} \leq 0.01\right)$

$\operatorname{STEC}\left(\mathrm{X}^{2}=\mathbf{7 . 7 6 0}, \mathrm{p} \leq \mathbf{0 . 0 1}\right)$ 
Table (4): Prevalence rates of E. coli in human samples in relation to their characteristics.

\begin{tabular}{|c|c|c|c|c|c|c|c|c|c|c|}
\hline \multirow{3}{*}{ Variable } & \multicolumn{5}{|c|}{ Urine } & \multicolumn{5}{|c|}{ Stool } \\
\hline & \multirow[t]{2}{*}{$\begin{array}{l}\text { Total No. } \\
\text { examined }\end{array}$} & \multicolumn{2}{|c|}{$\begin{array}{l}\text { Positive } E \text {. } \\
\text { coli samples }\end{array}$} & \multicolumn{2}{|c|}{$\begin{array}{c}\text { STEC / } \\
\text { Positive E. } \\
\text { coli samples }\end{array}$} & \multirow[t]{2}{*}{$\begin{array}{l}\text { Total No. } \\
\text { examined }\end{array}$} & \multicolumn{2}{|c|}{$\begin{array}{l}\text { Positive } E \text {. } \\
\text { coli samples }\end{array}$} & \multicolumn{2}{|c|}{$\begin{array}{c}\text { STEC / } \\
\text { positive } E \text {. } \\
\text { coli samples }\end{array}$} \\
\hline & & No. & $\%$ & No. & $\%$ & & No. & $\%$ & No. & $\%$ \\
\hline $\begin{array}{c}\text { Gender: Male } \\
\text { Female }\end{array}$ & $\begin{array}{l}41 \\
59\end{array}$ & $\begin{array}{l}13 \\
29\end{array}$ & $\begin{array}{l}31.71 \\
49.15\end{array}$ & $\begin{array}{l}1 \\
5\end{array}$ & $\begin{array}{l}7.69 \\
17.24\end{array}$ & $\begin{array}{l}33 \\
67\end{array}$ & $\begin{array}{l}24 \\
42\end{array}$ & $\begin{array}{l}72.72 \\
62.68\end{array}$ & $\begin{array}{c}17 \\
9\end{array}$ & $\begin{array}{l}70.83 \\
37.50\end{array}$ \\
\hline $\begin{array}{r}\text { Age/year: } \leq 10 \\
11-20 \\
21-30 \\
31-40 \\
41-50 \\
\geq 51\end{array}$ & $\begin{array}{c}19 \\
11 \\
33 \\
25 \\
7 \\
5\end{array}$ & $\begin{array}{c}8 \\
4 \\
16 \\
11 \\
2 \\
1\end{array}$ & $\begin{array}{c}42.11 \\
36.36 \\
48.48 \\
44 \\
28.57 \\
20\end{array}$ & $\begin{array}{l}\mathbf{1} \\
\mathbf{0} \\
\mathbf{3} \\
\mathbf{2} \\
\mathbf{0} \\
\mathbf{0}\end{array}$ & $\begin{array}{c}12.50 \\
0 \\
18.75 \\
18.18 \\
0 \\
0\end{array}$ & \begin{tabular}{r|r|}
34 \\
24 \\
21 \\
15 \\
4 \\
2
\end{tabular} & $\begin{array}{c}27 \\
13 \\
14 \\
9 \\
2 \\
1\end{array}$ & $\begin{array}{c}79.11 \\
54.16 \\
66.67 \\
60 \\
50 \\
50\end{array}$ & $\begin{array}{l}10 \\
5 \\
6 \\
3 \\
1 \\
1\end{array}$ & $\begin{array}{c}37.04 \\
38.46 \\
42.86 \\
33.33 \\
50 \\
100\end{array}$ \\
\hline $\begin{array}{ll}\text { Contact } & \text { with } \\
\text { poultry: Yes } & \\
\text { No } & \end{array}$ & $\begin{array}{l}64 \\
36\end{array}$ & $\begin{array}{l}31 \\
11\end{array}$ & $\begin{array}{l}48.43 \\
30.55\end{array}$ & $\begin{array}{l}4 \\
2\end{array}$ & $\begin{array}{c}12 \\
18.18\end{array}$ & $\begin{array}{l}58 \\
42\end{array}$ & $\begin{array}{l}49 \\
17\end{array}$ & $\begin{array}{l}84.48 \\
40.47\end{array}$ & $\begin{array}{c}19 \\
7\end{array}$ & $\begin{array}{l}38.78 \\
41.18\end{array}$ \\
\hline $\begin{array}{c}\text { Season: Summer } \\
\text { Autumn } \\
\text { Winter } \\
\text { Spring }\end{array}$ & $\begin{array}{l}21 \\
18 \\
23 \\
38\end{array}$ & \begin{tabular}{c|}
6 \\
9 \\
11 \\
16
\end{tabular} & $\begin{array}{l}28.57 \\
50.00 \\
47.82 \\
42.10\end{array}$ & $\begin{array}{l}\mathbf{0} \\
2 \\
1 \\
3\end{array}$ & $\begin{array}{c}0 \\
22.22 \\
9.09 \\
18.75\end{array}$ & $\begin{array}{l}13 \\
21 \\
26 \\
40\end{array}$ & $\begin{array}{c}7 \\
13 \\
17 \\
29\end{array}$ & $\begin{array}{l}53.84 \\
61.90 \\
65.38 \\
72.50\end{array}$ & $\begin{array}{c}3 \\
4 \\
6 \\
13\end{array}$ & $\begin{array}{l}42.85 \\
30.76 \\
35.29 \\
44.43\end{array}$ \\
\hline
\end{tabular}

Table (5): Occurrence of GAD and virulence genes in E. coli isolates from poultry

\begin{tabular}{|c|c|c|c|c|c|c|c|c|c|c|c|c|}
\hline \multirow{3}{*}{$\begin{array}{c}\text { E. coli } \\
\text { genes }\end{array}$} & \multirow{3}{*}{ 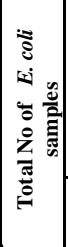 } & \multirow{2}{*}{ 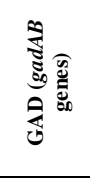 } & \multicolumn{8}{|c|}{ Virulence genes } & \multirow{2}{*}{ 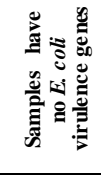 } & \multirow{2}{*}{ 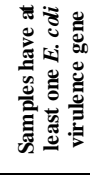 } \\
\hline & & & It & St & Bfp & eaeA & Stx1 & Stx2 & Ial & Aafll & & \\
\hline & & $\begin{array}{l}\text { No. } \\
(\%)\end{array}$ & No. $(\%)$ & No (\%) & $\begin{array}{l}\text { No. } \\
(\%)\end{array}$ & $\begin{array}{l}\text { No } \\
(\%)\end{array}$ & $\begin{array}{l}\text { No. } \\
(\%)\end{array}$ & $\begin{array}{l}\text { No. } \\
(\%)\end{array}$ & $\begin{array}{l}\text { No. } \\
(\%)\end{array}$ & $\begin{array}{l}\text { No. } \\
(\%)\end{array}$ & No. $(\%)$ & No. $(\%)$ \\
\hline $\begin{array}{l}\text { Farm } \\
\text { chickens }\end{array}$ & 30 & $26(86.7)$ & $4(13.3)$ & $5(16.7)$ & $\mathbf{0}(\mathbf{0 . 0})$ & $5(16.7)$ & $1(3.3)$ & $7(23.3)$ & $\mathbf{0}(\mathbf{0 . 0})$ & $\mathbf{0}(\mathbf{0 . 0})$ & $14(46.67)$ & $16(53.3)$ \\
\hline $\begin{array}{c}\text { Back } \\
\text { yard } \\
\text { chickens }\end{array}$ & 30 & $28(93.3)$ & $4(13.3)$ & $7(23.3)$ & $0(0.0)$ & $7(23.3)$ & $2(6.7)$ & $3(10)$ & $\mathbf{0}(\mathbf{0 . 0})$ & $\mathbf{0}(\mathbf{0 . 0})$ & $13(43.33)$ & $17(56.7)$ \\
\hline Ducks & 30 & $26(86.7)$ & $2(6.7)$ & $6(20)$ & $\mathbf{0}(0.0)$ & $7(23.3)$ & $3(10)$ & $5(16.7)$ & $\mathbf{0}(\mathbf{0 . 0})$ & $\mathbf{0}(0.0)$ & $12(40)$ & $18(60)$ \\
\hline Geese & 30 & 28(93.3) & 1(3.3) & $6(20)$ & $\mathbf{0}(0.0)$ & $6(20)$ & $1(3.3)$ & $7(23.3)$ & $0(0.0)$ & $\mathbf{0}(0.0)$ & $14(46.67)$ & $16(53.3)$ \\
\hline Turkeys & 30 & $27(90)$ & $5(16.7)$ & $7(23.3)$ & $\mathbf{0}(0.0)$ & $5(16.7)$ & $2(6.7)$ & $7(23.3)$ & $\mathbf{0}(0.0)$ & $\mathbf{0}(\mathbf{0 . 0})$ & $9(30)$ & $21(70)$ \\
\hline Total & 150 & $135(90)$ & $16(10.7)$ & $31(20.7)$ & $\mathbf{0}(\mathbf{0 . 0})$ & $30(20)$ & $9(0.6)$ & $29(19.3)$ & $\mathbf{0}(\mathbf{0 . 0})$ & $\mathbf{0}(\mathbf{0 . 0})$ & $62(41.3)$ & $88(58.7)$ \\
\hline
\end{tabular}


Table (6): Occurrence of GADA and virulence genes in E. coli isolates from humans

\begin{tabular}{|c|c|c|c|c|c|c|c|c|c|c|c|c|}
\hline \multirow{3}{*}{$\begin{array}{c}\begin{array}{c}\text { E. coli } \\
\text { genes }\end{array} \\
\text { Type of } \\
\text { samples }\end{array}$} & \multirow{3}{*}{ 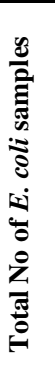 } & \multirow{2}{*}{ 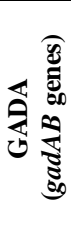 } & \multicolumn{8}{|c|}{ Virulence genes } & \multirow{2}{*}{ 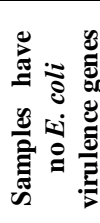 } & \multirow{2}{*}{ 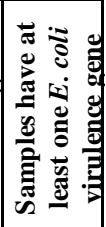 } \\
\hline & & & $\Xi$ & $\vec{\infty}$ & $\stackrel{\oplus}{\oplus}$ & $\underset{\Xi}{\Im}$ & $\bar{x}$ & $\tilde{z}$ & స్ & 馬 & & \\
\hline & & $\begin{array}{l}\hat{\theta} \\
\dot{b}\end{array}$ & $\frac{\hat{\theta}}{\dot{8}}$ & 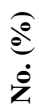 & $\frac{\widehat{\theta}}{\dot{8}}$ & $\begin{array}{l}\hat{\theta} \\
\dot{b}\end{array}$ & $\begin{array}{l}\hat{\theta} \\
\dot{\delta}\end{array}$ & $\begin{array}{l}\hat{\theta} \\
\dot{8}\end{array}$ & $\begin{array}{l}\hat{\theta} \\
\dot{8}\end{array}$ & $\begin{array}{l}\hat{Q} \\
\dot{8}\end{array}$ & $\begin{array}{l}\widehat{d} \\
\hat{z}\end{array}$ & $\begin{array}{l}\hat{\theta} \\
\dot{z}\end{array}$ \\
\hline 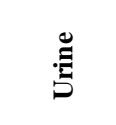 & లి & 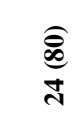 & త్రీ & త్ర్త్ & $\begin{array}{l}\hat{\theta} \\
\stackrel{\theta}{0} \\
\text { en }\end{array}$ & $\begin{array}{l}\underset{d}{\stackrel{d}{d}} \\
\underset{\infty}{0}\end{array}$ & $\begin{array}{l}\stackrel{\theta}{e} \\
\stackrel{e}{0}\end{array}$ & ָூ & $\begin{array}{l}\stackrel{\theta}{\ominus} \\
\stackrel{\theta}{0}\end{array}$ & $\stackrel{\hat{\theta}}{\stackrel{0}{0}}$ & 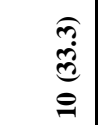 & 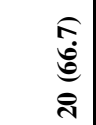 \\
\hline 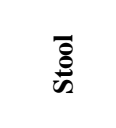 & लि & 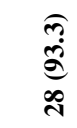 & త్ర్తి & $\begin{array}{c}\text { d. } \\
\text { d) }\end{array}$ & कृ & $\underset{\mathrm{e}}{\widehat{\Theta}}$ & ल? & $\begin{array}{l}\text { త్ } \\
\text { (ิ) }\end{array}$ & $\underset{\vec{\sigma}}{\stackrel{m}{2}}$ & $\underset{m}{\widehat{\theta}}$ & $\begin{array}{l}\hat{f} \\
\dot{d} \\
\dot{J}\end{array}$ & 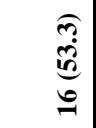 \\
\hline
\end{tabular}

\section{Discussion}

E. coli is part of the normal microbiota of the poultry intestine, but APEC strains can spread to other internal organs causing colibacillosis ( $\mathbf{L a}$ Ragione and Woodward, 2002). The current study included several species of domestic poultry representing the most common birds in Egypt. Thus, surveillance of $E$. coli in the intestinal contents of different birds provided a complete picture of its zoonotic implications and public health significance. In this study, the overall prevalence rate of $E$. coli in the examined poultry intestinal contents $(77.71 \%)$ was higher than that recorded by Mashhoor et al. (1987) in Egypt (50\%) and Heba (2012) $(43.1 \%)$ in chickens and $(27.2 \%)$ in ducks. The prevalence rate of $E$. coli in chickens was higher than that reported in Egypt by Heba, 2012 (43.1\%); Diab (2014) (43.6\%); Doaa (2015) (51.1\%) and Asmaa (2015) (52\%). Interestingly, the difference between the prevalence rates of $E$. coli among the examined domestic poultry was significant $(\mathrm{P} \leq 0.01)$. The infection rate was higher in the backyard poultry than farms which indicated lower sanitary conditions and a higher risk of interspecies transmission of the E. coli and zoonotic transmission as well.

In the present study, the E. coli isolation rate from ducks was nearly similar to that reported by Adzitey et al. (2012) (81.25\% to $87.93 \%$ ), whereas it was higher than that recorded by Heba (2012) (21.4\% to 35\%) in 
Egypt, Mbanga and Nyararai (2015) $(27.2 \%$ to $62.2 \%)$ and Diab, 2014 (57.7\%). In geese, the $E$. coli isolation rate was slightly higher than that reported by Mbanga and Nyararai (2015) (62.2\%). Moreover, the isolation rate of E. coli from turkeys, in this study, was higher than that recorded by $\boldsymbol{A b d} \boldsymbol{E l}$-Gawad (1995) (57.78\%) in turkey in Egypt. This variation in the isolation rates of $E$. coli among domestic poultry with those reported by others might be attributed to several factors such as geographical locations, management practice, breeding systems, immune status of the poultry, the standard of the biosecurity measures in farms, and sampling and examination techniques.

STEC is a well-known foodborne pathogen that has caused sporadic major outbreaks around the world (Yang et al., 2017). The public health threat posed by STEC has been highlighted by the morbidity and mortality associated with various outbreaks caused by this pathogen (Paton and Paton, 1998). In this study, the overall rate of STEC of positive $E$. coli poultry intestinal contents was $81.62 \%$, with high rates of STEC in backyard chickens (96.59\%), ducks $(93.02 \%)$, and farm chickens (91.43\%), followed by turkeys (51.43\%), and geese (41.67\%). A high significant difference was found between the isolation rates of STEC among the examined domestic poultry $(\mathrm{p} \leq 0.001)$. This finding indicated that a high percentage of $E$. coli isolates were potentially pathogenic in the examined domestic poultry and highlighting the role of this organism as a potentially important avian pathogen among poultry with economic impacts (Sahaly, 1995). Therefore, more precautions should be adopted to avoid food poisoning by avian colibacillosis particularly from poultry at marketing.

In humans, E. coli are the predominant non-pathogenic facultative flora of the intestine. some E. coli strains have acquired the ability to cause enteric or systemic disease in otherwise healthy people (Nataro and Kaper, 1998). In the present study, there was a significant difference between the isolation rates of $E$. coli of the human stool and urine samples $(\mathrm{p} \leq 0.05)$. The isolation rate of $E$. coli from human stool samples was higher than that reported in Ismailia province by Sahar et al. (2013) who reported that the isolation rates of E. coli were $31.4 \%$ (89/283) from the stool of patients with diarrhea and $16.6 \%(47 / 283)$ from the urine 
of humans with UTI and Magda et al. (2013) who isolated $E$. coli from human stool samples at a rate of $15 \%$ in Sharkia Province. The communityacquired UTIs that have been reported in Upper Egypt were potentials of the spread of multidrug-resistant strains that alarming the health significance of $E$. coli infection particularly zoonotic transmissions

(Hassuna et al., 2020).

The STEC strains can cause diarrhea, bloody diarrhea, hemorrhagic colitis in humans, and frequently result in HUS and renal failure (Tarr et al., 2005). Our study revealed that the overall isolation rate of STEC was $29.63 \%$ (32/54) of the positive $E$. coli human samples. There was a highly significant difference in the isolation rates of STEC between the human stool and urine samples $(\mathrm{p} \leq 0.01)$. The obtained results were nearly similar to those reported in Egypt by EL-Alfy et al. (2013) who found that the E. coli isolates were higher in human stool samples $(31.4 \%)$ than that reported in human urine (16.6\%) with UTI infections. The high percentage of $E$. coli isolates of human stool reflected the role of this organism as a potentially important human pathogen with public health impacts. Humans might serve as reservoirs for $E$. coli infection and transmission may occur by ingestion of contaminated food or water (Griffin and Tauxe, 1991).

In the present study, the prevalence rates of $E$. coli and STEC in the human samples in relation to gender were significantly higher in females than males in urine samples respectively ( $\mathrm{P} \leq 0.01)$, while it was higher in males than females in stool samples respectively $(\mathrm{P} \leq 0.01)$. This in agreement with that reported by Lo et al. (2013) who reported that E. coli was the most prevalent community-acquired uro-pathogens $(76.6 \%)$, with higher infection in females $(72.8 \%)$ and Lee and Kwon (2016) reported that more females than males had EHEC infections. Magliano et al. (2012) found that the overall $E$. coli accounted for $67.6 \%$ of all uropathogenic isolates from outpatients' clinics of an urban area of northern Italy and the $E$. coli isolation rate was lower in males aged $\geq 60$ years $(52.2 \%)$. E. coli was found to be less prevalent in the youngest and oldest male subjects $(51.3 \%$ and $52.2 \%$, respectively) and more frequent in female patients aged 15 years or older (71\%). However, the obtained result of STEC in human urine samples was inconsistent with that reported by Thorpe et al. (2001) who revealed that STEC- 
associated UTI was rare, and HUS rarely occurred after STEC-associated UTI in the USA. Our findings confirmed the result reported by Griebling (2007) who discovered that, for anatomical reasons, Women are more susceptible to UTI than men because their urethras are shorter, allowing bacteria easier access to the bladder.

Regarding age, the isolation rates of E. coli and STEC were higher in the age groups 21-30, 31-40 years. In stool samples, the detection rates of STEC were the highest in the age group $\geq 51$. This finding was consistent with that reported by Hill et al., (2006) who found that the association of $E$. coli infections with increasing age could be attributed to the declining of health conditions and immune status in elder ages. Regarding the high number of children being infected with $E$. coli, the young ages could be affected by immunity, hygienic measures, and contact with animals (Duffy, 2003 and Hill et al., 2006). However, Magliano et al. (2012) reported that $E$. coli was found to be less prevalent in the youngest and oldest male subjects $(51.3 \%$ and $52.2 \%$, respectively) and more frequent in female patients aged 15 years or older (approximately 71\%).

The prevalence rate of $E$. coli was significantly higher in group contacted poultry. This finding is reinforced by the result reported in Egypt by Naena (2009) who found that the $E$. coli isolation rate from persons in contact with chickens was $41.6 \%$. However, there was no significant difference $(\mathrm{p} \geq$ $0.05)$ in the detection rates of STEC in human samples in contacts and non-contacts of poultry. The obtained results confirmed that there are other sources of human infections with $E$. coli in addition to domestic poultry and humans might serve as reservoirs for $E$. coli infection and person-toperson transmission occurs. Transmission may also occur by ingestion of contaminated food or water (Griffin and Tauxe, 1991; Nataro and Kaper, 1998; Sahar et al., 2013; Magda et al., 2013; Mohamed, 2014 and Saikia and Joshi 2014). This added to the evidence that infection is spread by contact with other animals or through the water. As a result, risk mitigation should be focused more on infection pathways of $E$. coli in the environment (Solecki et al., 2008).

Regarding the season, in this study, the isolation rates of $E$. coli of human samples were higher than that reported in Egypt by Naena (2009) who found that the isolation rates of E. coli from stool samples of persons in contact with chickens 
in winter and summer seasons were $42.85 \%$ and $40 \%$, respectively in Egypt. The difference between the isolation rates of $E$. coli in the different seasons of human urine and stool samples was significant ( $p$ $\leq 0.05$ ). However, there were no significant differences between the isolation rates of STEC in the different seasons of human urine and stool samples. This finding was in contrast with that reported by Hill et al. (2006) who found that the number of reported cases of E. coli infections among humans increased during the summer months (1996-2004) in

\section{Louisiana, USA}

The overall detection rate of the E. coli GAD gene of the examined positive $E$. coli broth cultures of poultry and human samples was up to $90 \%$. This finding confirmed the result reported by McDaniels et al. (1996) who found that GAD genotypic assay detects a wider range of $E$. coli strains and is more specific for this species. Moreover, this assay should show greater quantitative sensitivity because it would target two highly homologous genes, gadA and $\operatorname{gadB}$, that appear to be commonly present in the E. coli genome (Smith, et al., 1992). The current finding deduced that the $\operatorname{gad} A B$ gene was prevalent in $E$. coli, including in the pathogenic $E$. coli groups. Therefore, The $\operatorname{gad} A B$ marker appears to be a good prescreening marker for $E$. coli, and it can be used in association with other trait virulence gene primers to detect pathogenic $E$. coli in poultry (Grant et al., 2001).

Virulence genes in E. coli The It, St, eaeA, Stx1, and Stx2 genes were found in the tested positive E. coli broth cultures of the poultry intestinal contents, but the Bfp, Ial, and Aafll genes were not. Similarly, Dutta et al. (2011) discovered that out of ten STEC chicken isolates, one contained only stx 2 , one carried stx2 and hlyA, four carried stx1, stx2, and hlyA, two carried stx1, eae A, and hlyA genes, and two carried stx1 and eaeA genes. Two EPEC chicken isolates carried both eaeA and hlyA genes, one just eaeA gene, and one only hlyA gene. Similarly, Kagambèga et al. (2012) detected the $E$. coli virulence genes using 16-plex PCR in primary cultures from feces of chickens slaughtered for human consumption in Burkina Faso. These virulence genes were indicated the presence of DEC in $48 \%$ of chicken fecal samples. Virulence genes of EHEC, EPEC, ETEC, EAEC and EIEC were detected in $6 \%$, $37 \%, 5 \%, 6 \%$ and $1 \%$ respectively. Momtaz and Jamshidi (2013) found that all of the EHEC-positive samples 
from chicken carried stx l, eaeA, and ehly virulence genes, whereas only $5(9.8 \%)$ of the AEEC group carried stx 1 , stx 2 , and $e a e A$ genes.

Mohamed (2014) recovered STEC isolates of poultry in Egypt and found that $63.63 \%$ of the examined samples carried stx1. Whereas $72.72 \%$ of samples carried stx2 and both alleles were present in $36.36 \%$ of examined isolates. Manges (2016) in his study on E. coli infection in geese, it was detected stx2 variant in $20.8 \%$ of geese fecal samples in Canada.

The rates of examined positive E. coli broth culture poultry samples have at least one E. coli virulence gene was consistent with Dutta et al. (2011) who found that high rate of the $E$. coli isolates from chicken samples $(33.33 \%)$ carried at least one virulence gene in India. The current research indicated that a high percentage of $E$. coli isolates of poultry were potential pathogenic in these birds. This reflects the role of this organism as a potentially important avian pathogen among poultry with economic impacts (Sahaly, 1995).

The detected E. coli virulence genes in the examined positive E. coli broth cultures of human urine and stool samples were consistent with that reported by Ogata et al. (2002) who identified the eaeA-positive $E$. coli bacteria in $7(3.6 \%)$ of 192 tourists who had visited Asia between April 1998 and March 1999. The organisms were detected in stool samples of patients as the only potential enteric pathogen in 13 cases with aggR and 4 cases with eae A gene.

The rates of examined positive E. coli broth cultures of human urine and stool samples have at least one E. coli virulence gene were indicated that a high percentage of $E$. coli isolates of human samples were potentially pathogenic in humans. This reflects the role of this organism as a potentially important human pathogen with medical importance (Obi et al., 2004).

Based on the obtained results in the current research with the detection of $E$. coli virulence genes; It, St, eaeA, Stx1, and Stx2 in the examined human and poultry samples, a welldocumented ability of avian $E$. coli to spread to human beings. It should be considered whether APEC could act as human PEC or as a reservoir of virulence genes for PEC (Rodriguez-Siek et al., 2005). As a zoonotic bacterium, avian E. coli has a significant influence on animal health and poses a public health threat (Manges et al., 2007; Lyhs et al., 2012; Aslam et al., 2014) 
In conclusion, our study confirmed that poultry intestinal contents are important sources of zoonotic $E$. coli with virulence gene attributes that illustrate many similarities to those found in E. coli isolates from humans. The high prevalence rates of $E$. coli and STEC in the examined intestinal contents of different poultry species and humans indicated a high risk of food contamination by pathogenic strains of these bacteria and reflects the role of this organism as a potentially important avian pathogen with economic and public health impacts. Therefore, persons in contact with domestic poultry should follow the perfect hygienic measures during the handling and management of poultry to reduce their infection with zoonotic $E$. coli strains. In addition, food safety measures should be taken to design and implement a comprehensive strategy to combat E. coli infections, which includes mandatory health education and promotion in endemic areas. Further studies are recommended on molecular subtyping of virulence markers associated with zoonotic $E$. coli isolates from poultry.

\section{References}

Abd El -Gawad, Khaled Ali Youssef(1995) Studies on some bacterial diseases of turkeys in Egypt. Master Degree - Zagazig University. Faculty of Veterinary Medicine. Department of Poultry Diseases. Adzitey, F., Liew, C. Y., Aronal, A. P., Huda, N. (2012) Isolation of Escherichia coli from ducks and duck-related samples. Asian J. Anim. Vet. Adv. 7(4), 351-355.

Aslam, M., Toufeer, M., Narvaez Bravo, C., Lai, V., Rempel, H. Manges, A., Diarra, M.S. (2014)

Characterization

Extraintestinal Pathogenic Escherichia coli isolated from retail poultry meats from Alberta. Canada. Int. J. Food Microbiol. 177, 49-56.

Mohamed, Asmaa Sadat (2014): Molecular characterization of virulence genes from Shiga toxinproducing Escherichia coli isolated from chicken retail meat. Thesis (Master Degree) Mansoura University. Faculty of Veterinary Medicine.

Department of Bacteriology Mycology and Immunology.

Asmaa, Talaie Tolba (2015): Bacteriological and immunological studies on E.coli isolated from broiler with special reference to effect of fosfomycin. Thesis (master's degree) - Banha University. Faculty of Veterinary Medicine. Department of Bacteriology, Immunology and Mycology. 
Busani, L., Boccia, D., Caprioli, A., Ruggeri, F. M., Morabito, S., Minelli, F., ... \& Tozzi, A. E. (2006): Public health implications of a case of haemolytic-uraemic syndrome associated with a concomitant outbreak of mild gastroenteritis in a small rural community. Epidemiology \& Infection, 134(2), 407-413.

Busani, L., Boccia, D., Caprioli, A., M Ruggeri, F., Morabito, S., Minelli, F., Lana, S., Rizzoni, G., Giofrè, F., Mazzeo, M., Tozzi, A. E. (2006) Public health implications of a case of haemolytic-uraemic syndrome associated with a concomitant outbreak of mild gastroenteritis in a small rural community. Epidemiol.

Infect. 134(2), 407-413.

Diab, Mohammed Said AbdEl Hamid (2014) Role of poultry in transmission of infection with $E$. coli to man. Theses (Ph.D) - Sadat City University. Faculty of Veterinary Medicine. Department of Animal Hygiene and Zoonoses.

Doaa, Ali El Morsy (2015) Genotypic virulence markers of E. coli isolated from broiler farms in Menofyia governorate at different climatic conditions. Banha University. Faculty of Veterinary Medicine.

Department of Bacteriology, Immunology and Mycology.
Duffy, G. (2003) Verocytoxigenic Escherichia coli in animal faeces, manures and slurries. J. Appl. Microbiol. 94, 94S-103S.

Dutta, T.K. Roychoudhury, P. Bandyopadhyay, S. Wani, S.A. Hussain, I. (2011) Detection \& characterization of Shiga toxin producing Escherichia coli (STEC) \& enteropathogenic Escherichia coli (EPEC) in poultry birds with diarrhoea. Indian J. Med. Res.133, 541-545.

Dziva, F. and Stevens, M. P. (2008): Colibacillosis in poultry: unravelling the molecular basis of virulence of avian pathogenic Escherichia coli in their natural hosts. Avian Pathol. 37, 355-366.

EL-Alfy, Sahar M. Ahmed, Salwa F. Selim, Samy A. Abdel Aziz, Mohamed H. Zakaria, Amira M., Klena, John D. (2013): Prevalence and characterization of Shiga toxin O157 and non-O157 enterohemorrhagic Escherichia coli isolated from different sources in Ismailia. Egypt Afr. J. Microbiol. Res.7(21), 26372645.

Feng, P.C., Reddy, S. (2013) Prevalences of Shiga toxin subtypes and selected other virulence factors among Shigatoxigenic Escherichia coli strains isolated from fresh 
produce. Appl. Environ. Microbiol. 79(22), 6917-6923.

Griebling, TL. (2007) Urinary tract infection in women. In: Litwin MS, editor; Saigal CS. editor. Urology Diseases in America. Washington, DC: NIH Publication. 589-619.

Grant, M.A., Weagant, S.D., Feng, P. (2001) Glutamate decarboxylase genes as a prescreening marker for detection of pathogenic Escherichia coil groups. Appl. Environ. Microbiol. 67(7), 3110-3114.

Griffin, PM., Tauxe, RV. (1991) The epidemiology of infections caused by Escherichia coli $\mathrm{O} 157: \mathrm{H} 7$, other enterohemorrhagic E. coli, and associated hemolytic uremic syndrome. Epidemiol. Rev. 13, 60-98.

Hass una, NA., Khairalla AS., Farahat EM., Hammad AM., Abdel-Fattah M. (2020) Molecular characterization of Extended-spectrum $\beta$ lactamaseproducing $E$. coli recovered from community-acquired urinary tract infections in Upper Egypt. Sci Rep. 17;10(1),2772.

Heba, Roshdy Mohamed (2012): A study on virulence markers of Escherichia coli isolated from poultry. Thesis (Ph.D.) - Cairo University Faculty of Veterinary Medicine

- Department of Microbiology. Hill, D. D.; Owens, W. E., Tchounwou, P. B. (2006):
Prevalence of Escherichia coli O157:H7 Bacterial Infections Associated with the Use of Animal Wastes in Louisiana for the Period 1996-2004. Int. J. Environ. Res. Public Health. 3(1), 107-113.

Hirvonen, J.J., Siitonen, A., Kaukoranta, S.S. (2012) Usability and performance of CHROMagar STEC medium in detection of Shiga toxinproducing Escherichia coli strains. J. Clinical Microbiol. 50(11), 3586-3590.

Kagambèga, A. Martikainen, O. Siitonen, A. Traoré, AS. Barro, N. Haukka, K. (2012) Prevalence of diarrheagenic Escherichia coli virulence genes in the feces of slaughtered cattle, chickens, and pigs in Burkina Faso. Microbiology open. 1(3), 276-284.

Kape r, J.B. Nataro, J.P. Mobley, H.L. (2004) Pathogenic Escherichia coli. Nat Rev Microbiol. 2(2), 123140.

Karch, H. Tarr, P.I. Bielasze wska, M. (2005) Enterohaemorrhagic

Escherichia coli in human medicine. Int $\mathrm{J}$ Med Microbiol. 295

(6-7), 405-418.

Kathayat D, Lokesh D, Ranjit S, Rajashekara G. (2021) Avian Pathogenic Escherichia coli (APEC): An Overview of Virulence and Pathogenesis Factors, Zoonotic Potential, and 
Control Strategies. Pathogens. 12;10(4),467.

La Ragione, RM. Woodward, MJ. (2002) Virulence factors of Escherichia coli serotypes associated with avian colisepticemia. Res. Vet. Sci. 73 (1), 2735.

Lee, G.Y. Jang, H.I. Hwang, I.G. Rhee, M.S. (2009) Prevalence and classification of pathogenic Escherichia coli isolated from fresh beef, poultry, and pork in Korea. Int J Food Microbiol. 134(3), 196200.

Lee, W.C. Kwon, Y.H. (2016) Comparative study on the epidemiological aspects of enterohemorrhagic Escherichia coli infections between Korea and Japan, 2006 to 2010. Korean J Intern Med. 31(3), 579.

Lo, D.S. Shieh, H.H. Ragazzi, S.L. B., Koch, V.H.K., Martinez, M.B. Gilio, A.E. (2013) Community-acquired urinary tract infection: age and gender-dependent etiology. BJN. 35(2), 93-98.

Lyhs, U. Ikonen, I. Pohjanvirta, T. Raninen, K. Perko-Makela, P. Pelkonen, S. (2012)

Extraintestinal pathogenic Escherichia coli in poultry meat products on the Finnish retail market. Acta Vet Scand. 54- 64.

MacFaddin, J.F. (2000) Biochemical Tests for Identification of Medical
Bacteria, Williams and Wilkins. Philadelphia, PA. 113.

Magda, A.M.A. Ali, M.N.M. Maysa A.I.A. Merwad, A.M.A. Ahmed, H.A. Rasha M.A.G. Rasha, M.M.A. Rehab, E.M. (2013) Prevalence of Enterobacteriacea in Wild Birds and Humans at Sharkia Province; With Special. ed by Protein Profile Analysis.

J. American Science. 9 (4), 173-183.

Magliano, E. Grazioli, V. Deflorio, L. Leuci, A. I. Mattina, R. Romano, P. Cocuzza, C.E. (2012) Gender and age-dependent etiology of community-acquired urinary tract infections. The scientific world J. 2012. 349597.

Manges, A.R. Escherichia coli and urinary tract infections: the role of poultry-meat. European Society of Clinical Microbiology and Infectious Diseases. Published by Elsevier Ltd.

Manges, A.R. Smith, S.P. Lau, B.J. Nuval, C.J. Eisenberg, J.N. Dietrich, P.S. Riley, L.W. (2007) Retail meat consumption and the acquisition of antimicrobial resistant Escherichia coli causing urinary tract infections: A case-control study. Foodborne Pathog. Dis. 4,419-431.

Mashhoor, M.M.Z. El-din, A.M.W.K. Safwat, E.E.A. Hamed, Q.M. Kheir El-din, A.M.W. (1987) An 
epidemiological study of enteric bacteria in broiler chicken farms in Kaluobia governorate. Vet. Med. J. 35(2), 301-313.

Mbanga, J. Nyararai, Y.O. (2015) Virulence gene profiles of avian pathogenic Escherichia coli isolated from chickens with colibacillosis

Bulawayo.

in

Onderstepoort J. Vet. Res. 82 (1), 850.

Momtaz, H. Jamshidi, A. (2013) Shiga toxin-producing Escherichia coli isolated from chicken meat in Iran: Serogroups, virulence factors, and antimicrobial resistance properties. Poult. Sci. 92(5),1305-1313.

Mora, A. Lepez, C. Dabhi, G. Blanco, M. Blanco, J.E. Alonso, M.P. Herrera, A. Mamani, R. Bonacorsi, S. Moulin-Schoule ur, M. B lanco, J. (2009) Extraintestinal pathogenic Escherichia coli O1:K1:H7/NM from human and avian origin: detection of clonal groups B2 ST95 and D ST59 with different host distribution. BMC Microbiol. 9:132

Mughini-Gras, L. Van Pelt, W. Van der Voort, M. Heck, M. Friesema, I. Franz, E. (2018) Attribution of human infections with Shiga toxin-producing Escherichia coli (STEC) to livestock sources and identification of source-specific risk factors, The Netherlands (2010-2014).
Zoonoses Public Health 65(1), e8-e22.

Naena, Ali Abd-Allah (2009) Diversity and prevalence of Escherichia coli in chickens, environment and related persons. Thesis master. Vet Med. Microbiology Department Alexandria University.

Nataro, J.P. Kaper, J.B. (1998) Diarrheagenic Escherichia coli. Clini Micro Rev. 11 (1),142-201.

Obi, C.L. Green, E Bessong, P.O. Villiers, B. D. Hoosen, A.A. Igumbor, E.O. Potgieter, N. (2004) Gene encoding virulence markers among Escherichia coli isolates from diarrhoeic stool samples and river sources in rural Venda communities of South Africa. Water SA. 30 (1), $37-42$.

Ogata, K. Kato, R. Ito, K. Yamada, S. (2002) Prevalence of Escherichia coli possessing the eaeA gene of enteropathogenic $E$. coli (EPEC) or the aggR gene of enteroaggregative E. coli (EAggEC) in traveler's diarrhea diagnosed in those returning to Tama.Tokyo from other Asian countries Jpn J Infect Dis. 55(1),14-18.

Paton, A.W. Paton, J.C. (1998) Detection and characterization of shiga toxigenic Escherichia coli by using multiplex PCR assays for stx $x_{1}, \quad s t x_{2}, \quad$ eaeA, enterohaemorrhagic E. coli 
$h l y A, r f b \mathrm{O} 111$ and $r f b \mathrm{O} 157 . \mathrm{J}$

Clin Microbiol. 36:598-602.

Rodriguez-Siek,

K.E.

Giddings, C.W. Doetkott, C.

Johnson, T.J. Fakhr, M.K.

Nolan, L.K. (2005) Comparison

of Escherichia coli isolates

implicated in human urinary

tract infection and avian colibacillosis.

Microbiol.

151(6), 2097-2110.

Sahaly, M.E.

Characterization of E. coli isolated from broiler. Master's degree. Thesis (Microbiology) Fac. Vet. Med. Alex. Univ.

Sahar, M. E. Salwa, F. A.

Selim, S. A. Abdel Aziz, M. H. Amira, M. Z. John, D. Klena, J. D. (2013) Prevalence and characterization of Shiga toxin O157 and non-O157 enterohemorrhagic Escherichia coli isolated from different sources in Ismailia, Egypt. Afric J. Microbiol Res. 7(21), 26372645

Saikia, P., Joshi, S.R. (2014) A Study on the Occurrence of Non-O157 Shiga Toxin Producing Escherichia coli Isolates in Retail Chicken Meats Marketed in North-East India. Proc. Natl. Acad. Sci., India, Sect. B Biol. Sci. 84, 337-342.

Smith, D.K., Kassam, T., Singh, B. Elliott, J.F. (1992) Escherichia coli has two homologous glutamate decarboxylase genes that map to distinct loci. Bacteriol.

174 (18), 5820-5826.

Solecki, O., MacRae, M., Ogden, I., Strachan, N. (2008) Can the high levels of human verocytotoxigenic Esche richia coli $\mathrm{O} 157$ infection in rural areas of NE Scotland be explained by consumption of contaminated meat? J. Appl. Microbiol. 103(6), 2616-2621.

Tanabe, R.H., Vieira, M.A., Mariano, N.A., Dias, R.C., da Silva, R. V., Castro, C.M., Dos Santos, L.F., Camargo, C.H., Yamatogi, R.S., Rall, V.L.M., Hernandes, R.T. (2019) Identification and characterization of atypical enteropathogenic and Shiga toxin-producing Escherichia coli isolated from ground beef and poultry breast purchased in Botucatu, Brazil. Braz. J. Microbiol., 50(4), 1099-1103.

Tarr, P.I.; Gordon, C.A., Chandler, W.L. (2005) Shigatoxin-producing Escherichia coli and haemolytic uraemic syndrome. Lancet 25;365(9464), 1073-86.

Thorpe, C.M., Acheson, D.W. (2001) Testing of urinary Escherichia coli isolates for Shiga toxin production. Clin. Infect. Dis., 32(10), 1517-1518.

Yang, S.C., Lin, C.H., Aljuffali, I.A., Fang, J.Y. (2017) Current pathogenic Escherichia coli foodborne outbreak cases and therapy development. Arch. Microbiol., 199(6), 811-825. 


\section{تواجد الايشريشياكولاي في محتويات امعاء الدواجن واحتمالية الإصابة بها الإيا

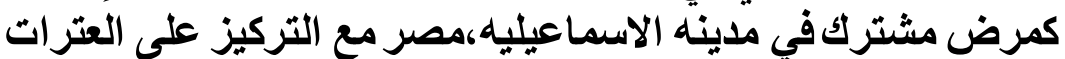 المنتجة لسم الشيجا (STEC)}

\section{الخلاصة}

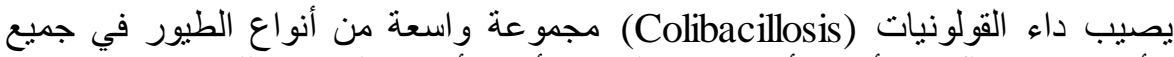

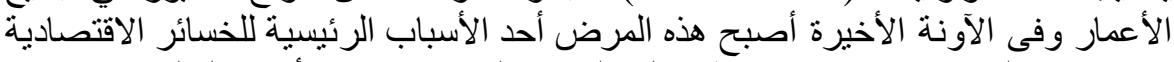

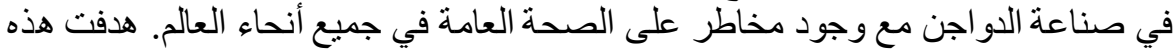

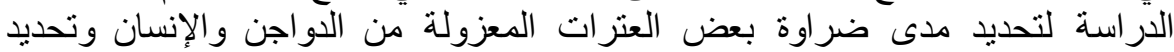

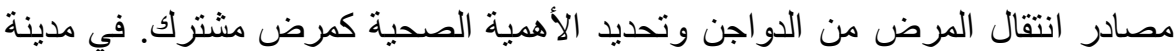

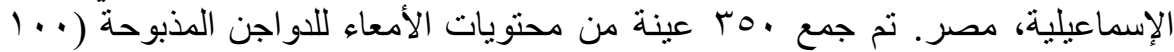

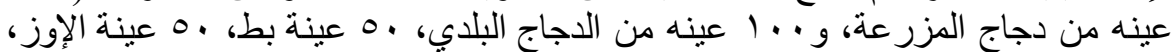

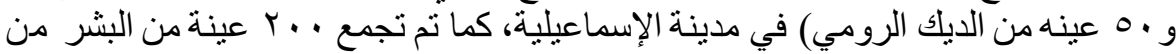

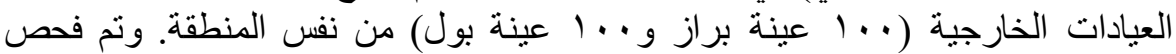

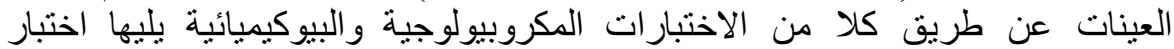

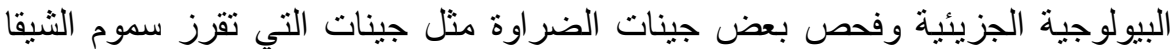

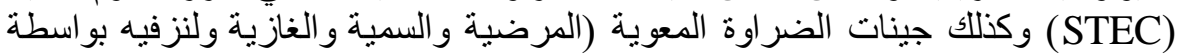

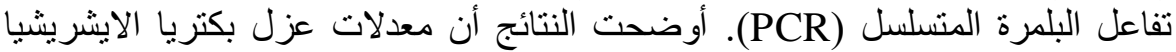

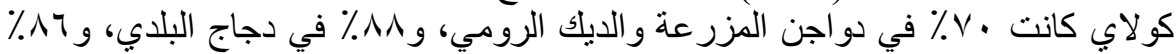

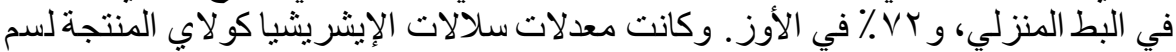
الثَيجا (STEC)

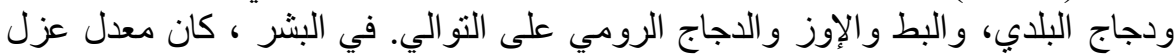

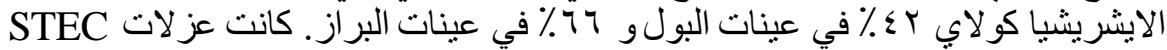

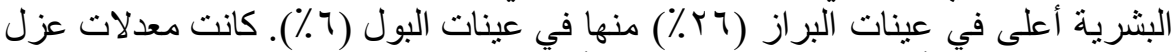

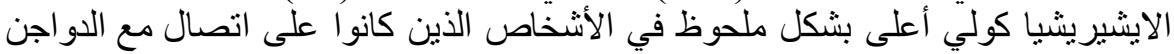

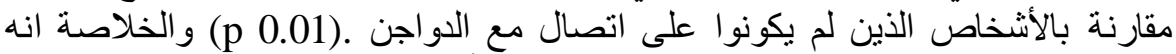

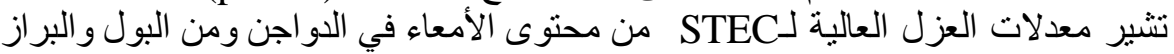

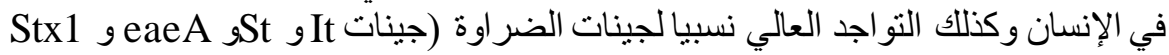

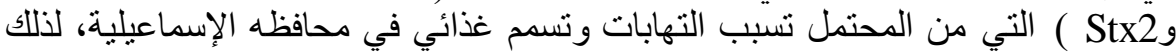

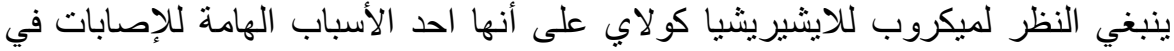

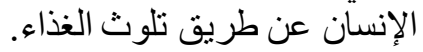

